\title{
A Norse Contribution to the History of Neurological Diseases
}

\author{
Trygve Holmøy \\ Department of Neurology, Ullevål University Hospital, Oslo, Norway
}

\section{Key Words}

Multiple sclerosis · Medical history · Norse saga

\begin{abstract}
Multiple sclerosis (MS) is prevalent in areas with many inhabitants of Scandinavian descent, and a 'Viking gene' hypothesis has been suggested for the dissemination of the disease. It is therefore relevant to search Norse sagas for descriptions of clinical pictures which could have been MS. The saga of Bishop Thorlak describes a woman named Halldora, who suffered from transient paresis between 1193 and 1198. The diagnosis is uncertain, but the story shows that symptoms associated with MS were known in Iceland at the end of the 11th century.
\end{abstract}

Copyright (C) 2006 S. Karger AG, Base

Pearce [1] has reviewed the history of multiple sclerosis (MS) back to 1822 . The disease could be much older [2], but reliable sources are scarce. Since MS is frequent among people of Scandinavian descent, it has been suggested that its dissemination may be linked with the Vikings' voyages [3]. We have therefore reviewed the Norse sagas to find evidence of MS in medieval Norway and Iceland. However, most sagas are focused on feuds and struggles for power, and not much is written about women's health. Nevertheless, Biskupa Sogur, the bishops' sagas, contains several accounts of diseases and afflictions [4]. Poser [3] discussed whether Halla, who was blind and deaf for two weeks between 1293 and 1323 and miraculously cured, suffered from MS [4].

Bishop Thorlak died in 1193. In 1199, the Elder Book of Portents, which contains accounts of the earliest miracles performed by Thorlak, was read aloud at the Allting by his successor [5]. Among the tales of convulsions, burns, bad beer and other abominations cured by Thorlak, we find this story:

There was a young woman named Halldora. She fell ill of a serious disease and had to keep to her bed and even be cared for in bed. She could not walk and could hardly sit, and her limbs were almost without strength; she had to be carried everywhere. She often suffered great pain, which caused her much distress. She was tended by her loving family, who were greatly worried about her condition. In spite of the many prayers offered for her, her symptoms only improved for a short while. When she had lain in bed for almost three years, it became more and more usual to make vows to Bishop Thorlak, whose holiness was talked of in every home. Then one of the men said, 'I believe it will be a sign of Bishop Thorlak's miraculous power if he were to cure Halldora, who has lain in bed for three years.' Many people agreed that the bishop would be able to obtain this favour from God if he wished. This happened on the Vestmanna Islands. A married woman whose word was reliable dreamt that a man in a black cloak came to her, and she understood that this was the holy Bishop Thorlak. He said, 'Tell her of this revelation and tell her that she must go to Skalholt if she wishes to be cured.' (...) When it became possible to leave the islands, Halldora began her journey and was carried to Skalholt on a stretcher. As soon as she saw the church at Skalholt her heart became lighter than it had been since she fell ill. She arrived several days before the church festival and grew better every day. Many people came to the festival, and Bishop Paul told them to pray for her. (...) The day after the festival she went to the Allting and of-

\section{KARGER}

Fax +4161306 1234 E-Mail karger@karger.ch www.karger.com
(C) 2006 S. Karger AG, Base 0014-3022/06/0551-0057\$23.50/0

Accessible online at: www.karger.com/ene
Trygve Holmøy

Department of Neurology

Ullevål University Hospital

NO-0047 Oslo (Norway)

Tel. +47 22119 101, Fax +47 23073 510, E-Mail trygve.holmoy@medisin.uio.no 
fered up a gold ring, and a few days later she rode to the Allting, where the whole assembly of the Ting could see that she was completely cured.

Halldora was cured after Thorlak's death in 1193 and before the Elder Book of Portents was read out in 1199, and is probably over 100 years older than the cure of Halla. The story was written down a few years after it had occurred and then read aloud publicly at the Allting by Bishop Paul [6], which makes it likely that the core content is truthful. It served as evidence of one of the miracles for which Thorlak was canonized. Nothing more is known about Halldora. The paralysis apparently lasted too long to be compatible with the usual course of a neurological disorder. However, there were short periods of improvement. It is possible that the symptoms were exaggerated in order to dramatise the saint's healing power, and that the actual course of the disease corresponded more to relapsing-remitting MS, chronic inflammatory demyelinating polyradiculoneuropathy or a neuromuscular transmission disorder. Hysteria is always suspected when miraculous cures occur, but in such cases the improvement is usually sudden and not spread over several days [7]. Although it is impossible to make a precise diagnosis, the saga does show that temporary paralysis was well known in medieval Iceland.

\section{Acknowledgement}

The excerpt from Thorlaks Saga was translated into English by Alison Arderne Olsen at The Norwegian Ministry of Foreign Affairs.

\section{References}

1 Pearce JM: Historical descriptions of multiple sclerosis. Eur Neurol 2005;54:49-53.

2 Medaer R: Does the history of multiple sclerosis go back as far as the 14th century? Acta Neurol Scand 1979;60:189-192.

3 Poser CM: Viking voyages: the origin of multiple sclerosis? An essay in medical history. Acta Neurol Scand Suppl 1995;161:11-22.
4 Anonymous: Thorlaks Saga; in Biskupa Sogur. Editiones Arna Magnaenae C, ch. 120, series A, vol 13.2. Copenhagen, Jon Helgason, 1978.

5 Anonymous: Den gamle jærtegnsbok om Biskop Thorlak. Odense, Odense University Press, 1984, pp 54-55.
6 Anonymous: Pauls Saga; in Biskupa Sogur. Copenhagen, Icelandic Literary Society, 1858, pp 127-148.

7 Ziegler J: Practitioners and saints: medical men in canonization processes in the thirteenth to fifteenth centuries. Soc Hist Med 1999;12:191-225. 